\title{
A Customer Touch Point Management System for Effective Service Communication
}

\author{
Sang Ki Lee \\ Lee International IP \& Law Group, Seoul, Korea
}

Objectives: Customer touch point management system (CTPMS) is a service communication management tool used by an insurance company ("the Company") in Korea. This system was originally introduced to improve the quality of service communication; however, it is now operating to prevent customer complaints in advance and to improve customer lifetime value (CLV). This case report is intended to examine the service communication management system currently used in the field.

Methods: This case report is a brief single-case study. This study introduces methods used to classify customers and grade customers by calculating customer value. We also review service communications made according to customer classification and grade. Then, we revisit re-purchase and referral topics, which are highlighted in the service-profit chain, together with service activities defined by the CTPMS.

Results: Ultimately, the Company's service strategy is embedded in the CTPMS. The Company intends to provide better service to customers with higher CLV, that is, those who contribute more profits to the company. The Company also focuses on preventing potential complaints from attention-required customers by taking preemptive measures.

Conclusions: The message that the Company's CTPMS conveys to the management is quite clear: an increase in CLV and the management of those who complain are the most important factors in service communication.

Key Words: Service Communication, Customer Touch Point Management System, Customer Lifetime Value, Customer Classification, Service-Profit Chain

\section{Introduction}

Customer Touch Point refers to the point where a customer is in contact with a company when a product or service is delivered. Customer touch point management system (CTPMS) started

Received: Nov 13, 2017 Revised: Dec 5, 2017 Accepted: Dec 9, 2017

Corresponding author: Sang Ki Lee

Lee International IP \& Law Group, 14F Poongsan Bldg., 23 Chungjeong-ro, Seodaemun-gu, Seoul 03737, Korea

Tel: +82-10-3667-3301, E-mail: 1sk77424@gmail.com

This is an Open Access article distributed under the terms of the Creative Commons Attribution Non-Commercial License (http://creativecommons.org/licenses/bync/4.0/) which permits unrestricted non-commercial use, distribution, and reproduction in any medium, provided the original work is properly cited. Copyright $\odot 2018$ Korean Association for Business Communication. based on the "Plan-Do-See" process with an aim to improve service communication to customers. The CTPMS comes in handy when companies set up a business plan for the next year. In preparation for the next year's business plan, companies perform an in-depth analysis of communication records made during the year, focusing on when (or what period), what, by whom, for what purpose (reason), and via what communication tool (telephone, mail, email, SNS, etc.) communication was made and on detailed customer responses to each incidence of service communication. In this process, CTPMS serves as a useful tool to get results (Lee, Gu, \& Jeon, 2016).

Since the CTPMS has been introduced in the Company, the system has evolved into an important management tool by which 
customer lifetime value (CLV) has substantially increased. At the beginning of its introduction, it was merely one of many approaches to improve service communication. After several years, the CTPMS has enabled the Company to maintain a long-term contractual relationship with customers (policyholders) and a long-term retention of insurance policies and add-sales to existing customers, which, ultimately, has expanded the Company's profitability. As demonstrated in this case, the importance of service communication is particularly emphasized in the insurance industry than in others.

\section{Case Description}

As mentioned in the introduction, the Company's initial purpose of adopting CTPMS was to improve service communication. However, at present, the Company uses the CTPMS as a means to increase CLV and prevent customer complaints, focusing on providing better services to customers who contribute more to the Company (Kim, Jung, Suh, \& Hwang, 2006). The Company also seeks to encourage re-purchases by existing policyholders through proactive communication based on the CTPMS. Further, the CTPMS is expected to help the Company establish a systematic service communication system thereby promoting the Company's brand image.

\section{Customer Classification and Customer Grade}

The Company classifies its customers into three categories: ordinary customers, contributing customers, and attention-required customers. An ordinary customer is classified as level 2 to 5 and a contributing customer as level 1, VIP and VVIP. Apart from these levels, the Company sets aside a group of customers, called attention-required customers, and manages them separately. Attention-required customers are those for whom no service agents are assigned, mostly because service agents initially assigned to them no longer work for the Company. The Company tries to provide differentiated services for this group as the customers are not able to receive any personal services from service agents.

The Company periodically performs a task to measure grades of existing customers (policyholders). Customer grades are de- termined based on monetary value that is calculated using different weights by product type and premium payment period. Once weights are assigned to the calculation, the Company can calculate the monthly converted premium (MCP) value of each customer. MCP is calculated by multiplying monthly premium by conversion rates (weights) by product type and by premium-paid period. The weights applied to calculate MCP are reviewed and determined by internal experts like insurance actuaries and accountants. The conversion rates are recalculated based on the company's profit and loss analysis at least once a year.

As an example, conversion rates by product type are shown in Table 1 below. Conversion rates for periods of premium payment are determined by the following formula:

$$
\begin{gathered}
\text { Conversion rate for premium-paid period } \\
=100 \%+(\text { numbers of premium-paid months } \times 1 \%)
\end{gathered}
$$

VVIP and VIP grades are calculated on a monthly basis, and other grades are calculated on a quarterly basis. Table 2 below shows customer grades according to MCP value. However, the head of the service team is given discretionary authority to raise the customer grade by one level to deal with unexpected situations.

\section{Service Communication by Customer Classification}

Service communication discussed here does not include any kinds of communication set forth by insurance laws and regulations (e.g. Insurance Status Report, Lapse Notice, etc.) or inbound service such as responses to customers' inquiries. In the Company's CTPMS, service communication to any groups of customers is handled by the customer service representatives

Table 1. Conversion rate by product type

\begin{tabular}{lcccc}
\hline Product type & $\begin{array}{c}\text { Savings, } \\
\text { UL, VUL }\end{array}$ & $\begin{array}{c}\text { VA, } \\
\text { Annuities }\end{array}$ & Term Life & Whole Life \\
\hline $\begin{array}{l}\text { Conversion } \\
\text { rate (\%) }\end{array}$ & 100 & 130 & 250 & 500 \\
\hline
\end{tabular}

UL, Unit Linked; VUL, Variable Universal Life; VA, Variable Annuity.

\begin{tabular}{|c|c|c|c|c|c|}
\hline MCP value & $>50$ M KRW & $>30$ M KRW & $>20$ M KRW & $>10$ M KRW & \\
\hline Grade & VIP-Gold & VVIP-Silver & VVIP-Bronze & VIP & \\
\hline MCP value & >3 M KRW & >1 M KRW & $>0.5 \mathrm{M} \mathrm{KRW}$ & $>0.2 \mathrm{M} \mathrm{KRW}$ & $<0.2$ M KRW \\
\hline Grade & Level 1 & Level 2 & Level 3 & Level 4 & Level 5 \\
\hline
\end{tabular}

Table 2. Customer grades by MCP value

MCP, Monthly Converted Premium. 
(CSRs) of the Company. We will examine in this session what kinds of service communications are made and the qualifications required for such CSRs according to different types of customers.

Service communication to ordinary customers is handled by CSRs who have more than two years of consulting experience and life insurance licenses. They provide service communications to customers mainly using SNS (Kakao Talk or other texting platforms). The ordinary customers receive, among other messages, a message celebrating their 1st anniversary of the insurance contract, a notice of insurance policy maturity, birthday greetings, and New Year's greetings via Kakao Talk or text messages from CSRs.

CSRs, who provide services to contributing customers, are mainly senior CSRs with at least three years of consulting experience, multiple insurance licenses and the Certificate of Korea Life Underwriter (CKLU). Contributing customers will receive an automatic call routing service, a service in which an inquiry call from contributing customers is automatically allocated to superior CSRs. In addition to basic SNS communications such as a birthday celebration, New Year's greetings and a notice of policy maturity, contributing customers also receive thank-you letters and gifts when their policies mark their 5th and 10th subscription anniversary.

For attention-required customers, the Company operates a call center exclusively assigned to them. Through this exclusive call center, the Company tries to solve customer dissatisfaction caused by the absence of service agents by proactively calling them. These customers are managed by CSRs who have more than five years of insurance service experience and multiple insurance licenses and the CKLU. When insurance contracts of attention-required customers approach the 5th subscription anniversary, customers receive thank-you letters from the Company. As with other groups of customers, this group of customers also receives birthday and New Year's greetings through SNS application from the Company. The difference, however, is that when the date of annuity payment or maturity of insurance policy comes near, they receive both SNS messages and telephone calls as notification. Additionally, in the case of a protection-type insurance policy, which covers the risk of the insured, if it lapses due to the suspension of premium payment, a CSR gives an outbound call to encourage the reinstatement of the policy, a service ultimately aimed to protect the insured.

\section{Discussion}

According to the service-profit chain model that Heskett, Jones, Loveman, Sasser, and Schlesinger (1994) have explored, proper service activities ultimately increase the revenue and profitability of service companies. Service companies often anticipate that the outcome of their service activities will lead to customer's re-purchases and referrals. And customer repurchases and referrals increase revenue and profitability of companies (Yi \& Lee, 2006; Yi, Lee, \& Sirh, 2009; Lee \& Gu, 2014b). Therefore, service activities are an important factor for many services companies, including the insurance business. The insurance business, by its nature, always seeks to maintain insurance contracts as long as they can, and thus their top priority is to maintain a great relationship with customers (Herington \& Johnson, 2010). The management of insurance companies understands quite well that it is always cost effective to have their existing customers re-purchase new insurance products and make referrals to their family members or friends in order to produce better margins (Lee \& Gu, 2014a).

Meanwhile, service activities in the Company are led by its CTPMS seeking a long-term relationship with customers, improving their policy persistency rate and adding sales to the existing customers. Ultimately the Company aims to increase customer lifetime value and improve company brand image as a whole using the CTPMS.

According to the research provided by Jones and Sasser (1995), customers are classified into four groups - Hostages, Terrorists, Mercenaries, and Apostles - based on customer satisfaction and customer loyalty. The Apostles is a group of ideal customers to every company as they show a high degree of satisfaction and loyalty to a company. Likewise, the CTPMS has been invented to provide higher customer satisfaction and induce higher loyalty from customers. However, as it was practitioners in the field who developed this system, there was no opportunity for the system to be reviewed theoretically or academically. When companies launch new tactics or programs operating in a fiercely competitive market, it is often the case that they focus more on a costs \& benefits analysis and a time-to-market issue in the decision-making process.

All things considered, the CTPMS may seem to be incomplete for now, but the message it conveys to us is quite clear. It provides the management of service companies with guidance on how to create service activities, especially service communication, with limited resources (Hallowell, 1996; Suh, Kim, \& Park, 2011). The Company is taking a simple strategy: provide more services to customers contributing more and give top-tier CSRs to attention-required customers, who may raise complaints regarding the lack of personal services from service agents. This approach indicates more focus on the management of customer complaints than the enhancement of service communication (Rust \& Chung, 2006). The company is strategically allocating 
more resources and skilled professionals to customers with higher customer lifetime values. In other words, the company is strategically using the CTPMS to prevent 'Terrorists' and to develop 'Apostles', as Jones and Sasser's (1995) study instructs.

\section{Conclusion}

In the introduction of this case report, we reviewed the purpose of CTPMS, customer classification and grading methods, assignment of CSRs, and contents of service communication for each group of customers of the Company. As mentioned above, the CTPMS has been initially developed in order to enhance the ways and quality of service communication so that it becomes a useful business planning process. In this effort, the Company collected all communication records provided to customers and then analyzed types, methods, frequencies, contents, and effects of service communications given during the previous years. However, since this system was introduced, people in the Company have realized that service activities should be able to change flexibly in order to increase revenue and improve the profitability of the insurance business.

\section{References}

Hallowell, R. (1996). The relationship of customer satisfaction, customer loyalty, and profitability: An empirical study. International Journal of Service Industry Management, 7(4), 27-42.

Herington, C., \& Johnson, L. W. (2010). The relationship-serviceprofit-chain: Conceptual framework and propositions. International Journal of Services Technology and Management, 14(2-3), 144-162.
Heskett, J. L., Jones, T. O., Loveman, G. W., Sasser, W. E., \& Schlesinger, L. A. (1994). Putting the service profit chain to work. Harvard Business Review, 72(2), 164-174.

Jones, T. O., \& Sasser, W. E. (1995). Why satisfied customers defect. Harvard Business Review, 73(6), 88-99.

Kim, S. Y., Jung, T. S., Suh, E. H., \& Hwang, H. S. (2006). Customer segmentation and strategy development based on customer lifetime value: A case study. Expert Systems with Applications, 31(1), 101-107.

Lee, S. K., \& Gu, J. W. (2014a). Applying the service-profit chain model to the contact center service business: MPC. Journal of the Korea Service Management Society, 15(3), 65-93.

Lee, S. K., \& Gu, J. W. (2014b). Exploratory study on the effective path of service-profit chain model's factors: Focusing on the employees of customer contact centers. The Academy of Customer Satisfaction Management, 14(4), 1-23.

Lee, S. K., Gu, J. W., \& Jeon, J. W. (2016). Service delusion. Seoul, Korea: Human House.

Rust, R. T., \& Chung, T. S. (2006). Marketing models of service and relationships. Marketing Science, 25(6), 560-580.

Suh, J. W., Kim, Y. T., \& Park, Y. J. (2011). A study on relationship between service standardization dimensions, perceived service quality, customer trust and customer satisfaction. Journal of Korea Service Management Society, 12(2), 237-259.

Yi, Y. J., \& Lee, C. L. (2006). The effects of customer satisfaction on firm's profitability and value. Korea Marketing Review, 21(2), 85113.

Yi, Y. J., Lee, J. Y., \& Sirh, J. Y. (2009). Internal marketing strategy for putting the service-profit chain to work: Hyundai Marine \& Fire Insurance. Asia Marketing Journal, 11(3), 225-249. 